\title{
Swords and Ploughshares: The Election Prerogative in Canada
}

\author{
JAMES LIGHTBODY University of Alberta
}

Modestly impressive by its lack of mention both in a recent examination of the political leadership of the prime minister and the more traditional texts of the Canadian political process, is serious notice of environmental limitations on the prime ministerial prerogative in dissolving the Legislative Assembly and announcing a general election. ${ }^{1}$

Perhaps the most remarkable feature of modern parliamentary government does remain in the prime minister's exclusive power to dissolve the legislature, thus deciding himself the time of the subsequent general election. The exercise of this prerogative clearly forms a powerful weapon in the electoral arsenal of the governing party. In this sense the decision of the cabinet on the calling of elections, except in the extraordinary circumstances surrounding want of confidence in the House, is likely to be significant to the extent that it has been based on their general appraisal of the constellation of favourable influences within the public arena. ${ }^{2}$

The apparent evolution of a functioning

'Thus, see Thomas Hockin, ed., Apex of Power: The Prime Minister and Political Leadership in Canada (Scarborough, 1971). Of the more traditional text approach, note R.M. Dawson, The Government of Canada, revised by Norman Ward (5th ed., Toronto, 1970), 205, 331-4; J.R. Mallory, The Structure of Canadian Government (Toronto, 1971), 85-6; M. Whittington and R.J. Van Loon, The Canadian Political System (Toronto, 1971), 287-8.

${ }^{2}$ There appears to be some debate as to the extent of the prime minister's personal power to dissolve the House without cabinet consultation and approval, despite earlier assertions that dissolution was vested as the special prerogative of the premier. For example, note A.D.P. Heeney, "Functions of the Prime Minister," in Paul Fox, ed., Politics: Canada (3rd ed., Toronto, 1970), 347. Assessing the evidence in this debate, Joseph Wearing fails to offer any definitive conclusion. "President or Prime Minister?" in Hockin, Apex of Power, 245-6. The matter is relatively tangential to the immediate concern, hence it will be sidestepped by suggesting that the decision is the prime minister's alone, acting upon such advice as he finds it politically expedient to solicit. Van Loon and Whittington find a similar convenient loophole, Canadian Political System, 288. three-party system in Canada raises the prospect, despite the irregularities and inequities built into the electoral system, of a return to minority government, and its possible eventual acceptance as the normal course of events. This being the case, if the system is not to be confronted with a perplexing series of elections as the government seeks an elusive "majority mandate," some curbs must reasonably be expected on the prime minister's powers of dissolution. ${ }^{3}$ Even if the avoidance of repeated costly elections were not reason enough, the oft-discarded concept of political fair play might suggest that the electoral system should not also add the timer's gun to the usual political advantages enjoyed by incumbent authorities. Hence, serious discussion of reform in the Canadian electoral system ought to include informed consideration of the possible regulation by statute of the announcement of elections. Such a move would naturally deviate radically from "classical" parliamentary practice, but similar major reforms of other aspects of the electoral system in Canada have been explicitly argued by K.Z. Paltiel and the Barbeau Committee in relation to election expenses, ${ }^{4}$ and implicitly suggested by Alan Cairns with respect to the representational translation of votes. ${ }^{5}$

${ }^{3}$ Denis Smith notes that both the parliaments of 1963-5 and 1965-8 might have gone their full term, but both were "... dissolved on the decision of the Prime Minister when he sensed the possibility of an electoral victory." "President and Parliament: The Transformation of Parliamentary Government in Canada," in Hockin, Apex of Power, 233.

${ }^{4}$ Paltiel also argues that a much restricted campaign period (four weeks) would assist in the institutionalization and statute regulation of party finance. Political Party Financing in Canada (Toronto, 1970), 141. In this he follows the Report of the Committee on Election Expenses (Ottawa, 1966), 37. A case can be made, but will not be in this instance, that statutory quadrennial elections would facilitate a more regular distribution of party financial solicitation, which in itself might render public supervision realistically practicable (to the extent of the reformist zeal of the government) by limiting the panic demands placed on party bagmen at frequent but irregular intervals.

5"The Electoral System and the Party System in Canada, 1921-1965," this Journal, I, no 1 (March 1968), 56.

Canadian Journal of Political Science/Revue canadienne de science politique, v, no 2 (June/juin 1972). Printed in Canada/Imprimé au Canada. 
In point of fact, the evidence indicates that such reform may be less drastic than it, at first, appears. For instance, eleven of the thirteen provincial general elections in Saskatchewan since 1920 (including the most recent on June 23, 1971) have been held in the month of June. It might well be argued from this that there exist in Saskatchewan certain environmental constraints which fetter the otherwise unlimited ministerial power of dissolution. To establish a permanent election date in the province of Saskatchewan one would, with an eye cocked to the historical pattern, clearly suggest the third week in the month of June. ${ }^{6}$

The argument may then be made that if, over a period of time, certain annual periods regularly appear to have been judged the most propitious for elections by a variety of political authorities (irrespective of party), then we are presented with an important clue as to the existence of certain constraints upon the electoral system which political actors expect will govern the conduct of campaigns, and presumably the attitudes of the electorate. Thus since $1920,{ }^{7}$ for instance, over one-half of prairie provincial campaigns (57.5 per cent) and one-third of federal campaigns have been conducted over the weeks immediately prior to, and into, the month of June (note Tables III, IV). These decisions reflect both the strong agricultural-rural orientation of the prairie

\footnotetext{
${ }^{6}$ Whether biennial, triennial, or quadrennial is, of course, another question to consider. As a more general comment one ought not, I think, to accept without serious reservation Cairns' pessimism regarding reform of the electoral system. He argues that "... the habituation of Canadians to the existing system renders policy oriented research on the comparative merits of different electoral systems a fruitless exercise." Ibid., 56. Yet, as T.H. Qualter indicates, there has been a variety of electoral system experimentation at the provincial level in western Canada. The Election Process in Canada (Toronto, 1970), 129-36. The possibilities for change and reform exist; probable realization is not fruitless, academic gum-beating but rather a question of political expediency, as any student of the patterns of redistribution in British Columbia can readily appreciate.

${ }^{7}$ The year 1920 was selected, arbitrarily, as the congealing point of the modern electoral system in Canada. Coincidentally, it marks the initial appearance of the continuing third or protest party parliamentary representation. For comments on the evolution of the modern electoral period, note Dawson and Ward, The Government of Canada, 320-2; Qualter, The Election Process, 3-4; and N. Ward, The Canadian House of Commons: Representation (2nd ed., Toronto, 1963), 211-32.
}

provincial governments (to an extent apparent even in Ontario) and a federal appreciation of the importance of agrarian influence. These political campaigns are conducted then in the bouyant optimism which follows seeding and precedes summer haying and tillage. The dearth of late fall elections (none in September, only four of forty-four in the last quarter) is an indication of the uncertainty with which the farm community, but also the government, approaches the harvest season, and of the general lack of time during this period for non-economic (read, political) pursuits. In those sectors of the country in which the pre-eminence of agriculture has been less pronounced (for instance, east of the Ottawa River), elections will tend naturally to be less closely bound to the agricultural cycle.

It is a commonplace that Canadian elections ought not to be conducted over the winter months. The modern evidence tends to support this dictum (only 10 of 145 campaigns were undertaken in the winter third of the year, or roughly 7 per cent) although for the earlier period of our examination the findings are less conclusive. The early proclivity towards winter elections may refiect either the stronger stuff of which our pioneers were made or the hardiness encouraged by the rampant consumption of alcohol, ${ }^{8}$ but more realistically resulted from the generally less stringent polling laws of the period, which customarily allowed a period of days (or in some cases, weeks) for the conscientious voter to acclimatize himself to the point of casting his ballot. ${ }^{9}$ Despite the marvels of modern transportation, it is obvious that the Canadian winter wrecks its campaign toll; thus, for one example, the avoidance of winter elections in Newfoundland takes into account the fact that the seasonal shutdown of the coastal steamers effectively isolates the outport communities.

Additionally, one of the greater stresses on the broader political system, which is a direct result of the harsh winter climate, develops from the problem of seasonal unemployment. ${ }^{10}$

${ }^{8}$ The classical decision of the Judicial Committee in Russell v the Queen (1882), as understood by Lord Haldane in 1925, resulted of course from the fact " ... that the evil of intemperance at that time amounted in Canada to one so great and so general that at least for the period it was a menace to the national life of Canada so serious and pressing that the National Parliament was called on to intervene to protect the nation from disaster." Noted by Dawson and Ward, The Government of Canada, 93n.

${ }^{9}$ Qualter, The Election Process, 30-1.

${ }^{10}$ For a brief discussion of climatic stress upon the political process, note the discussion by Van Loon and Whittington, Canadian Political System, 31. 

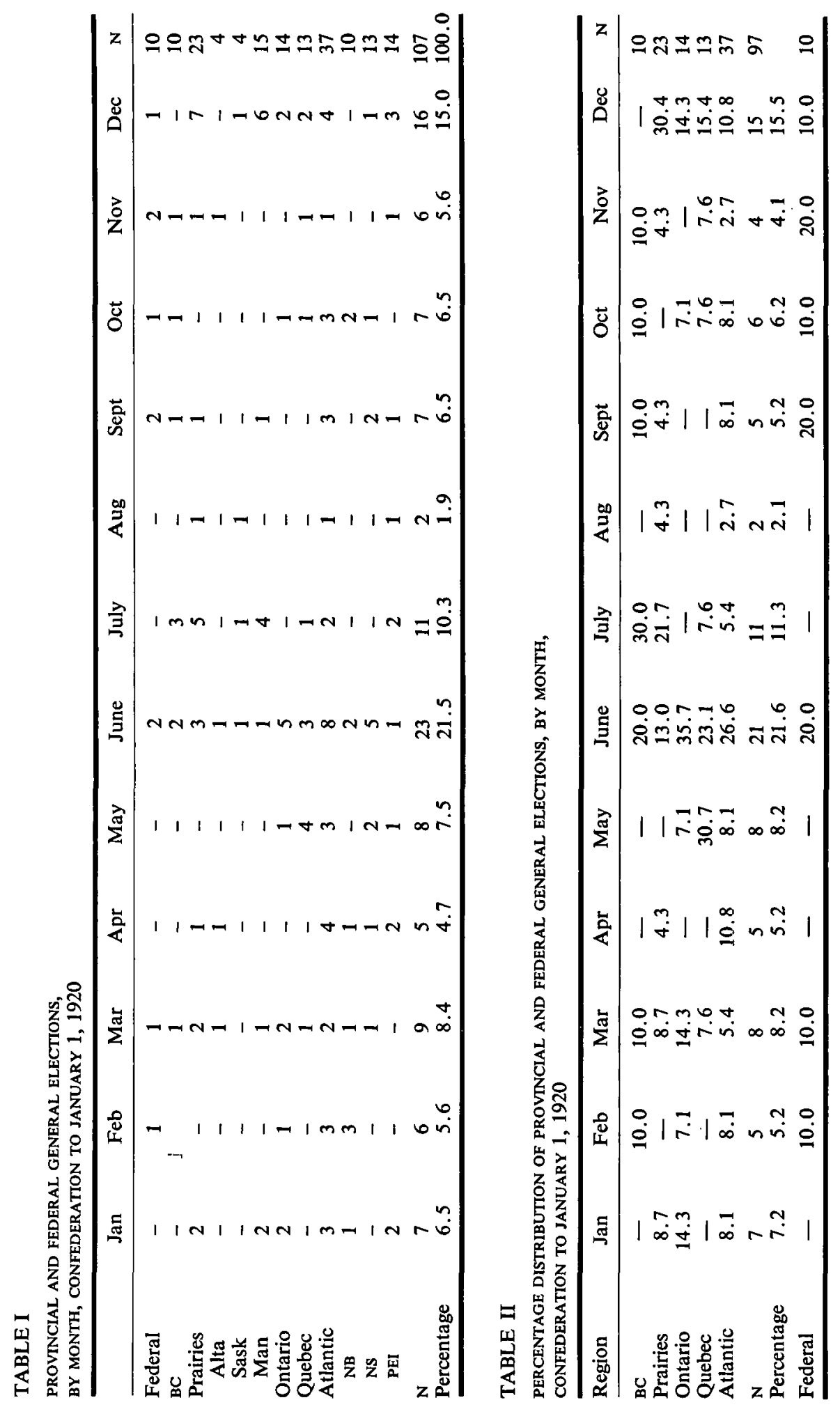

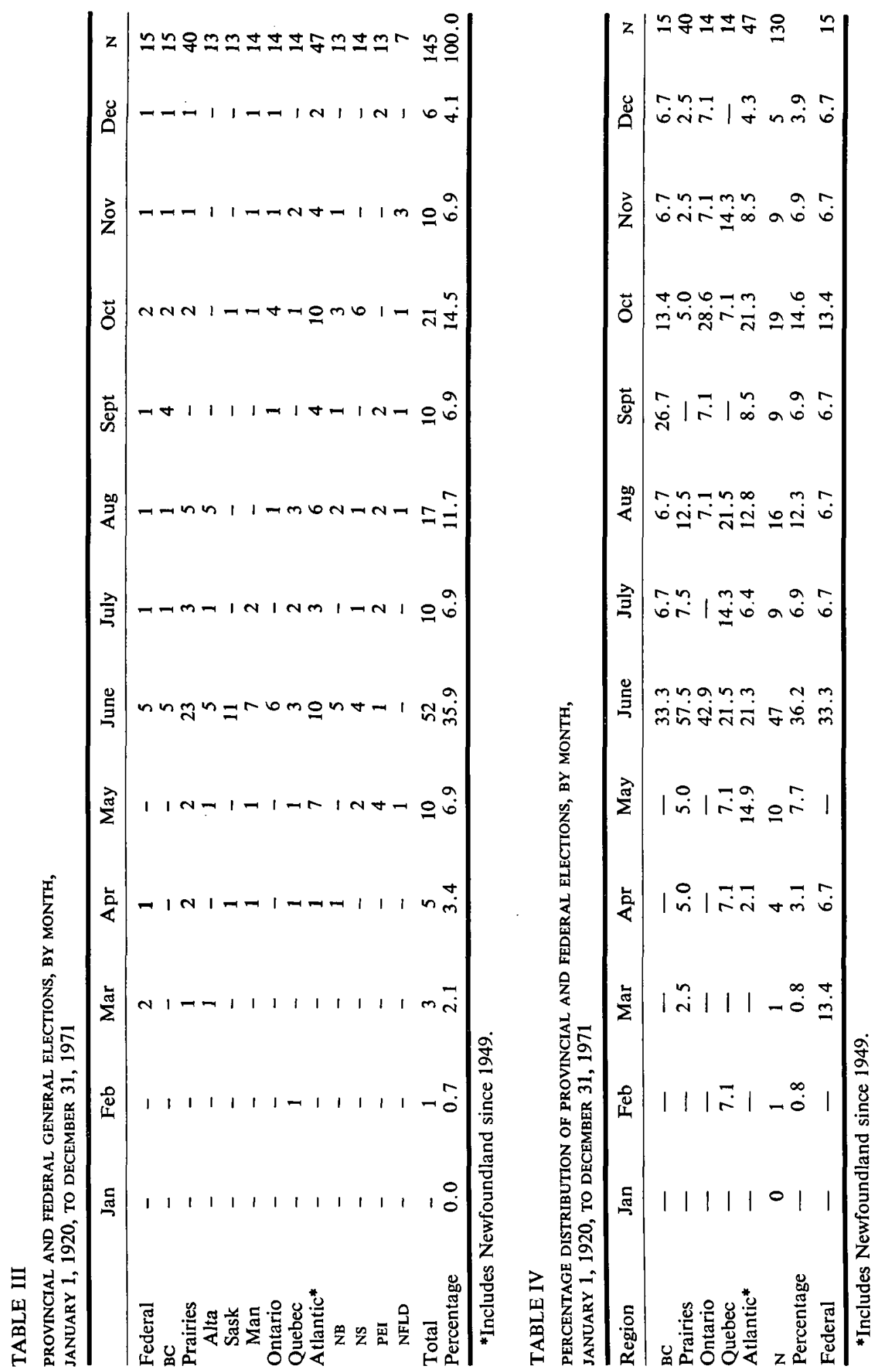
The addition of up to a quarter of a million voters to the list of unemployed Canadians probably constitutes a powerful disincentive to any first minister's desire for a winter campaign, and consequently appears as a factor more relevant to the dearth of winter elections in the more industrially oriented modern period. Similarly, May and June constitute excellent campaign periods to the extent that they are normally coincident with the return to work and, optimistically, the end of winter.

Other references, and naturally questions, may be drawn from the tables. For instance, conventional political wisdom maintains that election campaigns cannot be waged successfully over the vacation months of July and August, since it is believed impossible to generate the intensive energy necessary to sustain political action. However, the evidence here indicates that, at least in Alberta and the Atlantic provinces, this axiom may not, in fact, hold true. The special significance of the September-October election period to Ontario and Nova Scotia is less clear, although the influence of tradition and the impact of political precedents coupled to the normal innovative inertia of survival-oriented politicians ought not to be discounted in the environment of constraints which structure the decision for an election.

This short research comment should not be construed as a clarion call to the hypothetical institution of a Canadian "nation-wide election day," but it does suggest that certain environmental constraints do exist to restrict the apparent free exercise by first ministers of their powers to announce general elections. Denis Smith implicitly raises such a reform prospect in his advocacy of a new dimension in the modern powers of parliament and the gradual abandonment of the convention of confidence. ${ }^{11}$ If governments are no longer to be

11 "President and Parliament," 241. faced with the peril of dissolution following a reversal in the legislature, then it will perhaps eventually follow that the prime minister's electoral prerogatives will be considered anachronistic, and hence a power to be restricted.

What appears to be an implicit contradiction in the line of argument advanced above (that is, the prime minister has customarily established the time of election for either his government's advantage or the opposition's discomfort, or both; thus to posit an election day on the basis of traditional practices will institutionalize the latter's disadvantage) may only be resolved through more extensive analysis of the interaction among the various constraints affecting the setting of the date; for one example, to what extent will agricultural constraints restrict the decision of a premier wishing to take advantage of favourable polls? The Saskatchewan evidence suggests, irrespective of party, that the environmental constraint is the predominant factor; but to what degree may we generalize from this one case?

On this point as well, it should be noted that the tables do not differentiate elections precipitated by a government's defeat in the legislature from the normal case. The decision to include these occasional instances was based on an assumption (which might incidentally go some way in limiting the effects of the noted contradiction) that opposition party expectations of favourable election conditions are governed by motives and an appraisal of the general system similar to the government's own. This would suggest, then, that even a minority government in difficulties is unlikely to face serious legislative expression of want of confidence from mid-November until probably the end of February, barring irrational opposition behaviour. But the degree of the institutionalization of this process is, again, another point for exploration.

\section{The Regression Model of Regionalism: A Critique}

\section{N. H. CHI Carleton University}

Regionalism is a crucial - if not the crucial variable in any serious study of the Canadian "mosaic" system. Yet "regionalism" is never "operationalized" adequately. The researcher simply assumes that residence in Ontario or Newfoundland is an appropriate index of
"Ontarianism" or "Newfoundlandism." At best "regionalism" defined in such a crude manner is a convenient construct - a dummy

${ }^{1}$ Categorical thinking is valid as long as the concepts are clearly differentiated from each

Canadian Journal of Political Science/Revue canadienne de science politique, $v$, no 2 (June/juin 1972). Printed in Canada/Imprimé au Canada. 